\title{
Pendampingan manajemen pencegahan anemia pada remaja
}

\author{
Desi Oktariana $^{1 *}$, Evi Lusiana², Nia Savitri Tamzil², Gita Dwi Prasasty³ \\ 1Bagian Patologi Klinik, Fakultas Kedokteran, Universitas Sriwijaya, Indonesia \\ ${ }^{2}$ Bagian Farmakologi, Fakultas Kedokteran, Universitas Sriwijaya, Indonesia \\ ${ }^{3}$ Bagian Parasitologi, Fakultas Kedokteran, Universitas Sriwijaya, Indonesia \\ E-mail: desioktariana@fk.unsri.ac.id
}

\begin{abstract}
Abstrak
Anemia adalah suatu kondisi yang ditandai dengan berkurangnya jumlah sel darah merah dan/atau konsentrasi hemoglobin $(\mathrm{Hb})$. Prevalensi anemia di Indonesia berkisar antara $12 \%$ pada remaja laki-laki dan 23\% pada remaja perempuan, dengan proporsi anemia ada di kelompok umur 15-24 tahun dan 25-34 tahun. Pengetahuan tentang tingkat dan penyebab anemia pada masa remaja sangat lah penting, karena merupakan jendela peluang intervensi berbasis sekolah untuk meningkatkan kesehatan remaja. Tujuan kegiatan pengabdian masyarakat ini adalah untuk meningkatkan kesadaran para remaja mengenai pentingnya mencegah anemia, serta meningkatkan keterampilan para kader UKS dalam melakukan kegiatan yang bersifat preventif dan promotif terhadap pencegahan anemia di kalangan remaja. Metode yang dilakukan adalah dengan memberikan penyuluhan, melakukan pemeriksaan cek darah, serta memberikan pelatihan dan pendampingan kepada kader kesehatan di sekolah untuk melakukan kegiatan yang bersifat preventif dan promotif kepada siswa-siswa di sekolah menengah. Hasil yang didapatkan dari kegiatan ini adalah peningkatan pengetahuan siswa mengenai anemia, serta tindakan preventif dan promotif untuk pencegahannya.
\end{abstract}

Kata kunci: Anemia, Remaja, Pencegahan

\begin{abstract}
Anemia preventing management training accompaniment in adolescents. Anemia is a condition characterized by a reduction in the number of red blood cells and / or hemoglobin $(\mathrm{Hb})$ concentration. The prevalence of anemia in Indonesia ranges between $12 \%$ in adolescent boys and $23 \%$ in adolescent girls with the proportion of anemia in the age group of 15-24 years and 25-34 years. Knowledge of the level and causes of anemia in adolescence is very is important, because it is a window of opportunity for school-based interventions to improve adolescent health. The purpose of this activity is to increase the awareness of adolescent about the importance of preventing anemia, as well as improving the skills of UKS member in carrying out activities that are preventive and promotive towards preventing anemia among adolescents. The method used is to provide counseling, blood checks, and provide training and assistance to health cadres in schools to carry out activities that are preventive and promotive to students in schools. The results obtained from this activity are an increase in students' knowledge about anemia, as well as preventive and promotive measures to prevent it.
\end{abstract}

Keyword: Anemia, Adolescent, Prevention 


\section{PENDAHULUAN}

Anemia adalah suatu kondisi yang ditandai dengan berkurangnya jumlah sel darah merah dan/atau konsentrasi hemoglobin $(\mathrm{Hb})$. Anemia adalah masalah kesehatan masyarakat global yang mempengaruhi negara-negara berkembang dan maju dan memiliki konsekuensi besar bagi kesehatan manusia serta perkembangan sosial dan ekonomi, yang mempengaruhi 24,8\% dari populasi dunia. Beban yang diakibatkan oleh anemia bervariasi sesuai dengan usia seseorang, jenis kelamin, ketinggian tanah, dan kehamilan. Prevalensi anemia di seluruh dunia di kalangan remaja adalah 15\% (27\% di negara-negara berkembang dan 6\% di negara-negara maju). Di Indonesia, prevalensi anemia berkisar antara 12\% pada remaja laki-laki dan $23 \%$ pada remaja perempuan dengan proporsi anemia ada di kelompok umur 15-24 tahun dan 25-34 tahun. ${ }^{1,2}$

Perubahan fisik dan fisiologis yang terjadi pada remaja berdampak besar pada kebutuhan nutrisi remaja sehingga membuat para remaja lebih rentan terhadap kekurangan nutrisi. Remaja berisiko tinggi mengalami kekurangan zat besi dan anemia. Hal ini disebabkan pertumbuhan pubertas yang cepat dengan peningkatan tajam dalam massa tubuh tanpa lemak, volume darah, dan massa sel darah merah, yang meningkatkan kebutuhan zat besi untuk mioglobin dalam otot dan $\mathrm{Hb}$ dalam darah. Kebutuhan zat besi meningkat dua hingga tiga kali lipat dari yang sebelumnya $\sim 0,7-0,9 \mathrm{mg}$ zat besi/hari pada saat pra-remaja hingga menjadi sebanyak 1,37-1,88 $\mathrm{mg}$ zat besi/hari pada remaja laki-laki dan 1,40-3,27 mg zat besi/hari pada remaja perempuan. ${ }^{1,3}$

Anemia pada masa remaja memiliki implikasi serius dalam berbagai bentuk outcome, dan hampir semua konsekuensi fungsional dari kekurangan zat besi sangat terkait dengan keparahan anemia. Anemia pada remaja berdampak buruk terhadap penurunan imunitas, gangguan pertumbuhan fisik dan perkembangan mental, konsentrasi, prestasi belajar, kebugaran remaja dan produktifitas. Selain itu, secara khusus anemia yang dialami remaja putri akan berdampak lebih serius, mengingat mereka adalah para calon ibu yang akan 
hamil dan melahirkan seorang bayi, sehingga memperbesar risiko kematian ibu melahirkan, bayi lahir prematur dan berat bayi lahir rendah (BBLR). ${ }^{4}$

Intervensi untuk mengurangi beban anemia harus bertujuan untuk mengatasi penyebabnya. Strategi pencegahan dan pengendalian anemia yang berbasis efektivitas biaya harus didokumentasikan dengan baik dan memiliki kekuatan untuk memenuhi tujuan yang dimaksud di berbagai negara. Pengetahuan tentang tingkat dan penyebab anemia pada masa remaja sangat lah penting, karena merupakan jendela peluang intervensi berbasis sekolah untuk meningkatkan kesehatan remaja. Ada kelangkaan data tentang anemia pada remaja yang tinggal di negara berkembang dalam konteks ekologis yang kompleks dari kemiskinan, parasitisme, dan kekurangan gizi. Di semua tingkatan, efek negatif anemia selama masa remaja mengharuskan adanya tindakan kesehatan masyarakat. Sayangnya, karena inisiatif untuk mencegah anemia biasanya hanya menargetkan bayi, anak kecil, serta wanita hamil dan menyusui, dan belum tentu remaja, kebutuhan remaja mungkin tetap tidak terpenuhi dan konsekuensi anemia pada remaja terus berlanjut. ${ }^{5}$

Tujuan dari kegiatan pengabdian masyarakat ini adalah meningkatkan kesadaran dan pengetahuan para siswa menengah untuk mencegah dan mengidentifikasi anemia pada remaja sejak dini demi mencegah komplikasi lebih lanjut dan menghindari efek tidak diinginkan akibat adanya anemia, serta meningkatkan keterampilan para kader UKS dalam melakukan kegiatan yang bersifat preventif dan promotif terhadap pencegahan anemia di kalangan remaja.

\section{TINJAUAN PUSTAKA}

Prevalensi anemia pada remaja di negara berkembang masih sangat tinggi. Organisasi Kesehatan Dunia (WHO) mendefinisikan remaja sebagai populasi dalam kisaran usia 10-19 tahun. Remaja adalah periode transisi antara masa kanak-kanak dan dewasa ditandai dengan pertumbuhan dan perkembangan yang cepat yang menawarkan kesempatan kedua dan terakhir untuk mengejar ketertinggalan pertumbuhan dalam siklus hidup. Remaja 
memiliki berat 30\% dari berat dewasa mereka dan lebih dari 20\% tinggi dewasa mereka antara 10-19 tahun. Karena pertumbuhan dan perkembangan fisik yang luar biasa seperti itu, kebutuhan makro dan mikronutrien di kalangan remaja sangat tinggi sehingga membuat remaja menjadi kelompok fisiologis penting yang kebutuhan gizinya menuntut perhatian khusus. ${ }^{6}$

Anemia adalah suatu kondisi di mana jumlah sel darah merah menurun yang mengakibatkan kurangnya kapasitas pembawa oksigen dari sel darah merah untuk memenuhi kebutuhan fisiologis tubuh. Terdapat tiga penyebab anemia, yaitu kehilangan darah, peningkatan penghancuran sel darah merah (hemolisis), dan penurunan produksi sel darah merah. Secara global, kekurangan zat besi dianggap sebagai penyebab paling umum dari anemia. Namun, defisiensi nutrisi lainnya (termasuk defisiensi folat, vitamin B12 dan vitamin A), peradangan akut dan kronis, infeksi parasit, dan kelainan bawaan atau didapat yang memengaruhi sintesis hemoglobin, produksi sel darah merah, atau ketahanan sel darah merah semuanya dapat menyebabkan anemia. ${ }^{7}$

Anemia mempengaruhi kinerja kognitif, karakteristik perilaku, dan pertumbuhan fisik bayi, anak-anak prasekolah, dan usia sekolah. Anemia juga mempengaruhi status kekebalan dan morbiditas dari infeksi pada semua kelompok umur dan penggunaan sumber energi oleh otot. Oleh karena itu, kapasitas fisik dan kinerja kerja remaja dan orang dewasa dari semua kelompok umur sangat terpengaruh. Di antara remaja, anemia mempengaruhi tidak hanya status kesehatan saat ini, tetapi juga dapat memiliki efek buruk di kemudian hari. Tingkat kejadian berat bayi lahir rendah, prematuritas, kematian bayi dan neonatus di antara anak-anak menghasilkan banyak remaja perempuan yang kekurangan gizi. Kemudian, remaja perempuan yang kekurangan gizi ini menjadi anemia dan menghasilkan bayi berat lahir rendah..$^{8,9}$

Selama masa remaja, kebutuhan akan zat besi meningkat dari tingkat pra-remaja 0,70,9 mg Fe/hari hingga 2,2 mg Fe/hari baik di kalangan remaja laki-laki dan perempuan. Peningkatan kebutuhan zat besi ini disebabkan oleh perkembangan pubertas puncak yang 
ditandai dengan perluasan volume darah total, peningkatan massa tubuh tanpa lemak, dan timbulnya menstruasi pada wanita remaja. Kebutuhan zat besi pada wanita terus tetap tinggi setelah menarche karena kehilangan darah menstruasi di mana zat besi membutuhkan rata-rata sekitar $20 \mathrm{mg}$ zat besi per bulan dan mungkin juga setinggi $58 \mathrm{mg}$ pada beberapa individu. ${ }^{10,11}$

Di negara-negara berkembang, infeksi parasit dan penyakit menular lainnya sama banyaknya, sehingga dapat meningkatkan kebutuhan zat besi dalam tubuh manusia. Kualitas konsumsi makanan yang buruk selama masa kanak-kanak dan onset awal menarche dapat menyebabkan penipisan cadangan besi. Sejumlah besar remaja, khususnya wanita, memiliki asupan zat besi hanya 10-11 mg / hari yang menyumbang sekitar $1 \mathrm{mg}$ penyerapan zat besi ke dalam tubuh. Kondisi ini semakin rumit ketika remaja sering terpapar infeksi, beban kerja yang berat atau aktivitas fisik yang meningkat dan kehamilan dini pada wanita. ${ }^{12,13}$

Banyak faktor dan beragam berkontribusi terhadap anemia, dengan kekurangan zat besi menjadi penyebab paling umum. Bukti dari literatur menunjukkan bahwa remaja wanita; remaja dalam tahap awal masa remaja, perempuan dalam keadaan fisiologis seperti menstruasi, remaja dari status sosial ekonomi rendah, remaja dengan defisiensi makronutrien dan remaja dengan infeksi malaria dan cacing adalah lebih rentan terhadap pengembangan anemia. Selain itu, area tempat tinggal (pedesaan atau perkotaan) dan pola makan, sumber makanan keluarga, jumlah keluarga, dan status pendidikan keluarga adalah faktor umum yang terkait dengan anemia terutama di negara berkembang. ${ }^{14,15}$

\section{METODE}

Kegiatan pengabdian masyarakat ini dilakukan di SMP Negeri 9 Palembang. Khalayak sasaran kegiatan ini adalah 40 orang siswa sekolah menengah dan 10 orang kader UKS di sekolah menengah tersebut. Kader UKS dipilih karena mereka adalah orang yang berperan dalam melakukan kegiatan preventif dan promotif di lingkungan sekolah, dan 40 orang 
siswa lainnya diharapkan dapat membantu kegiatan preventif dan promotif tersebut di sekolah masing-masing. Kegiatan ini melibatkan empat orang dosen dengan latar belakang dokter umum yang telah mendapatkan sertifikasi kompetensi dokter layanan primer.

Dalam pelaksanannya, kegiatan dilaksanakan dengan metode sebagai berikut:

a. Penyuluhan, dilakukan dengan ceramah dengan alat bantu berupa power point yang disertai dengan gambar dan juga dilakukan diskusi dengan para siswa tentang penyebab anemia, jenis-jenis anemia, mekanisme terjadinya anemia, bahaya dan komplikasi yang mungkin timbul apabila anemia tidak dicegah dan tidak teridentifikasi dengan baik di masa remaja, dan manajemen untuk mencegah terjadinya anemia di kalangan remaja.

b. Demonstrasi dan pendampingan yaitu memberikan pelatihan dengan melibatkan secara langsung kader kesehatan UKS mengenai cara pemeriksaan cek darah sederhana sehingga dapat melakukan pemantauan kepada beberapa siswa sekolah yang berisiko anemia, serta memberikan pelatihan dan pendampingan kepada kader kesehatan di sekolah untuk melakukan kegiatan yang bersifat preventif dan promotif kepada siswasiswa di sekolah menengah untuk meningkatkan kesadaran tentang pencegahan anemia.

c. Melakukan pemeriksaan cek darah gratis sebagai skrining awal anemia pada siswasiswa sekolah menengah.

d. Pemantauan, untuk mengetahui keberhasilan dari kegiatan yang telah dilaksanakan oleh dosen dan siswa.

\section{HASIL DAN PEMBAHASAN}

Kegiatan ini dilakukan pada tanggal 28 November 2019 bertempat di SMP Negeri 9 Palembang. Registrasi peserta dimulai pada pukul 07.30 WIB. Acara dibuka setelah ketua pelaksana serta kepala sekolah membuka kegiatan ini. Kepala sekolah, guru, dan peserta sangat menyambut baik kegiatan ini. Kegiatan ini diharapkan dapat terus 
berkesinambungan dengan materi berbeda maupun materi yang sama di SMP Negeri 9 Palembang.

Pukul 08.00 WIB penyuluhan dimulai di ruang kelas VIII.3 dengan peserta yang hadir berjumlah 50 orang. Penyuluhan disampaikan oleh dr. Desi Oktariana dengan menggunakan media power point yang disambungkan ke LCD. Penyuluhan ini membahas tentang definisi anemia, penyebab anemia, jenis-jenis anemia, mekanisme terjadinya anemia, bahaya dan komplikasi yang mungkin timbul apabila anemia tidak dicegah dan tidak teridentifikasi dengan baik di masa remaja, dan manajemen untuk mencegah terjadinya anemia di kalangan remaja. Presentasi berlangsung selama 30 menit, dilanjutkan dengan sesi tanya jawab selama 15 menit. Peserta terlihat antusias dengan topik yang disampaikan. Sesi pre-test dan post test dilakukan untuk mengukur tingkat pengetahuan peserta mengenai topik yang dibahas. Setelah penyuluhan selesai, tim membagikan doorprize bagi siswa yang mampu menjawab pertanyaan dengan benar dan cepat.

Pukul 09.00 WIB, pemeriksaan kadar $\mathrm{Hb}$ darah gratis dilakukan sebagai skrining awal anemia pada siswa-siswa sekolah menengah. Kegiatan ini dilakukan bersama-sama oleh ketua dan anggota tim. Siswa diberi penjelasan mengenai manfaat dan prosedur yang akan dilakukan, kegiatan ini dilakukan atas kesediaan siswa tanpa paksaan dari pihak manapun. Pemeriksaan kadar $\mathrm{Hb}$ dilakukan dengan alat $\mathrm{Hb}$ meter, menggunakan strip $\mathrm{Hb}$ sekali pakai. Sebanyak 51 siswa memeriksakan kadar $\mathrm{Hb}$ darah mereka dengan sukarela. Kegiatan berlangsung sekitar 1 jam. $\mathrm{Hb}$ masing-masing siswa dicatat dalam lembar kegiatan.

Pukul 10.00 WIB, kegiatan dilanjutkan dengan demonstrasi dan pendampingan, yaitu memberikan pelatihan dengan melibatkan secara langsung kader kesehatan UKS mengenai cara pemeriksaan cek darah sederhana sehingga dapat melakukan pemantauan kepada beberapa siswa sekolah yang berisiko anemia, serta memberikan pelatihan dan pendampingan kepada kader kesehatan di sekolah untuk melakukan kegiatan yang bersifat preventif dan promotif kepada siswa-siswa di sekolah menengah untuk meningkatkan 
kesadaran tentang pencegahan anemia. Kader UKS yang dilatih berjumlah 10 orang. Kegiatan ini berlangsung selama kurang lebih 30 menit, dilanjutkan dengan pemantauan hasil pelatihan, yang dilakukan dengan cara meminta siswa melakukan kembali kegiatan yang telah dilatih.

Seluruh anggota tim berkoordinasi dan bertanggung jawab sesuai tugas masingmasing. Evaluasi dilakukan terutama saat pelatihan dalam kelompok kecil, karena dapat langsung memantau cara pemeriksaan kadar $\mathrm{Hb}$ darah yang benar, dan bagaimana cara melakukan kegiatan yang bersifat preventif dan promotif. Evaluasi ini dilakukan untuk menilai pemahaman peserta tentang topik yang diajarkan. Beberapa aspek yang dievaluasi:

1. Aspek kognitif
a. Peserta penyuluhan mengetahui definisi anemia
b. Peserta penyuluhan mengetahui jenis-jenis anemia
c. Peserta penyuluhan mengetahui mekanisme terjadinya anemia
d. Peserta penyuluhan mengetahui bahaya dan komplikasi yang mungkin timbul apabila anemia tidak dicegah dan tidak teridentifikasi dengan baik di masa remaja
e. Peserta penyuluhan mengetahui manajemen untuk mencegah terjadinya anemia di kalangan remaja.

2. Aspek afektif
a. $100 \%$ peserta menyatakan senang mendapatkan pemeriksaan kadar $\mathrm{Hb}$ darah, penyuluhan, dan pelatihan pendampingan manajemen pencegahan anemia pada remaja.
b. $100 \%$ peserta menyadari pentingnya pencegahan penyakit anemia pada remaja
c. $100 \%$ peserta menyatakan kegiatan pendampingan manajemen anemia pada remaja sangat bermanfaat.

3. Aspek psikomotor/tindakan
a. Peserta pelatihan mampu melakukan pemeriksaan cek darah sederhana dengan menggunakan alat $\mathrm{Hb}$ meter.


b. Peserta pelatihan mampu melakukan pemantauan kepada beberapa siswa sekolah yang berisiko anemia,

c. Peserta pelatihan mampu melakukan kegiatan yang bersifat preventif dan promotif kepada siswa-siswa lain di sekolah menengah untuk meningkatkan kesadaran tentang pencegahan anemia.

d. Peserta penyuluhan tampak antusias mengikuti penyuluhan dan aktif bertanya selama diskusi.

Sebagian besar peserta belum memiliki pengetahuan yang baik mengenai penyakit anemia, namun terjadi peningkatan pengetahuan setelah kegiatan dilaksanakan yang dinilai melalui rerata skor post-test yang lebih tinggi dibanding pre-test, dan juga dinilai pada saat diskusi tanya jawab. Pengetahuan tentang tingkat dan penyebab anemia pada masa remaja sangat lah penting, karena merupakan jendela peluang intervensi berbasis sekolah untuk meningkatkan kesehatan remaja. ${ }^{3}$

Pada saat dilakukan pemeriksaan darah, sebagian besar peserta memiliki kadar $\mathrm{Hb}$ yang normal, hanya ada sebagian kecil peserta yang memiliki kadar $\mathrm{Hb}$ dibawah rentang normal (anemia). Kadar $\mathrm{Hb}$ yang normal pada siswa menandakan tercukupinya kebutuhan gizi dari para siswa tersebut, mengingat penyebab anemia sangat terkait dengan asupan

gizi dan keberadaan infeksi. Anemia dapat dihindari dengan konsumsi makanan tinggi zat besi, asam folat, vitamin A, vitamin C dan zink, dan pemberian tablet tambah darah (TTD). ${ }^{7,14,15}$

Secara keseluruhan, kegiatan ini telah berkontribusi dalam membentuk kesadaran siswa mengenai pentingnya menjaga diri agar tidak terkena anemia, dan melakukan pola hidup yang baik agar kadar $\mathrm{Hb}$ yang rendah bagi beberapa siswa dapat terkoreksi dengan baik.

\section{SIMPULAN}

Kegiatan ini berjalan dengan lancar dan disambut baik oleh khalayak sasaran serta guru. Siswa dan siswi masih memiliki pengetahuan dan kesadaran yang rendah mengenai 
penyakit anemia. Pada akhir penyuluhan, sebagian besar peserta telah memiliki pengetahuan dan pemahaman yang baik mengenai penyakit anemia dan pencegahannya serta mampu melakukan pemantauan terhadap siswa lainnya dalam satu lingkungan sekolah. Dengan demikian, tujuan yang hendak dicapai dalam kegiatan ini telah berhasil.

\section{Ucapan Terima Kasih}

Kegiatan ini merupakan kegiatan pengabdian masyarakat yang dibiayai oleh dana PNBP Universitas Sriwijaya sesuai dengan surat perjanjian penugasan tenaga pelaksana pengabdian kepada masyarakat Aplikasi Iptek dan Seni Budaya Lokal Universitas Sriwijaya.

\section{Referensi}

1. De LM, Pena-Rosas RJP, Cusick S, et al. Hemoglobin Concentrations for the Diagnosis of Anemia and Assessment of Severity; Vitamin and Mineral Nutrition Information System. Vol 11. Geneva: World Health Organization; 2011:1.

2. Benoist BD, McLean E, Egli I, et al. Worldwide Prevalence of Anemia 1993-2005. Geneva: World Health Organization; 2008.

3. Balcı YI, Karabulut A, Gürse D, et al. Prevalence and risk factors of anemia among adolescents in Denizli, Turkey. Iran J Pediatr. 2012;22(1): 77-81.

4. Ciesla B. Hematology in Practice. 2nd ed. Philadelphia, PA: FA Davis Company; 2011.

5. Usha R. Nutritional Anemia. Boca Raton, FL: CRC press; 2001: 8-12.

6. World Health Organization. Prevention of Iron Deficiency Anemia in Adolescents: A Role of Weekly Iron and Folic Acid Supplementation. Geneva: World Health Organization; 2011.

7. Beard JL. Iron biology in immune function, muscle metabolism and neuronal functioning. J Nutr. 2001;131:568S-580S.

8. Halterman JS, Kaczorowski JM, Aligne CA, et al. Iron deficiency and cognitive achievement among school-aged children and adolescents in the United States. Pediatrics. 2001;107:1381-1386.

9. Jain M, Chandra S. Correlation between hematological and cognitive profile of anemic and non anemic school age girls. Curr Pediatr Res. 2012;16(2):145-149.

10. Goel S, Gupta B. Low anemia prevalence among adolescents of an urban hilly community. Indian J Community Med. 2007;32(1):67-68.

11. Baral K, Onta S. Prevalence of anemia amongst adolescents in Nepal a community based study in rural and urban areas of Morang District. Nepal Med Coll J. 2009;11(3):179-182. 
12. Kaur S, Deshmukh PR, Garg BS. Epidemiological correlates of nutritional anemia in adolescent girls of rural Wardha. Indian J Community Med. 2006;31(4):255-258.

13. Atto V, Bleyere NM, Konan BA, et al. Hematological profile of adolescents in Abidjan (Côte d'Ivoire). Int J Biosci. 2012;2(6):1-12.

14. Saratha A, Singh Z, Datta SS, et al. Prevalence of anemia among young adult female students in a medical teaching institution in Pondicherry. Indian J Matern Child Health. 2010;12(4):1-8.

15. Gupta A, Parashar A, Sharma ATD. Anemia among adolescent girls in Shimla Hills of north India: does BMI and onset of menarche have a role. Indian J Med Sci. 2012;66(5):126-130. 